CORRECTION

\title{
Correction to: Non cognitive skills and childcare attendance
}

\section{Daniela Del Boca ${ }^{1} \cdot$ Enrica Maria Martino $^{2} \cdot$ Chiara Pronzato $^{3}$}

(c) Springer Science+Business Media, LLC, part of Springer Nature 2021

Correction to: Review of Economics of the Household

$$
\text { https://doi.org/10.1007/s11150-021-09591-6 }
$$

The original version of this article unfortunately contained an error in Reference section.

In reference list, the author group is missing for the reference Biroli et al. (2018). The complete reference details are presented here.

The original article has been corrected.

\section{Reference}

Biroli P., Del Boca D., Heckman J.J., Pettler Heckman L., Koh Y.U.K., Kuperman S., Moktan S., Pronzato C.D., \& Ziff A.L. (2018). Evaluation of the reggio approach. Research in Economics 72(1), 1-32.

Enrica Maria Martino

enricamariamartino@gmail.com

1 Collegio Carlo Alberto, CesIfo, CEPR, Turin, Italy

2 CHILD_Collegio Carlo Alberto, Turin, Italy

3 University of Turin, Collegio Carlo Alberto, Dondena, Turin, Italy 